\title{
EFFICACY OF SOME BIOCONTROL ORGANISMS, ANIMAL MANURES AND FUNGICIDES ON CONTROLLING OF POTATO BLACK SCURF AND STEM CANKER DISEASE
}

\author{
M.A. Khalil, Seham S. Ragab and Amal M. Ismail \\ Plant Pathol. Res. Inst., Agric. Res. Centre, Giza, Egypt
}

Received: Nov. 13, 2018

Accepted: Jan. 21, 2019

\begin{abstract}
In the last few years, stem canker and black scurf disease caused by Rhizoctonia solani Kuhn (teleomorph Thanathephorus cucumeris [Frank] Donk) are among different diseases important attacked potato crop under the Egyptian climate conditions. Eight fungal isolates were isolated from diseased plants representing different localities in different governorates i.e. El-Kassasen (Ismailia Gov.), Kafer EIzayat (Gharbia Gov.), El-Katatba (Minofya Gov.), Housh-Essa (Behera Gov.), ElBadrashen (Giza Gov.), Behdal (Minia Gov.), Dairoot (Assiut Gov.) and Shandaweel (Sohag Gov.). The obtained isolates differed in their culture color, number and size of sclerotia. Isolates which isolated from El-Kassasen, Kafer El-zayat, El-Khatatba, ElBadrashen and Behdal, were belonging to AG-3 anastomosis group. Under greenhouse conditions this isolates were tested for their pathogenicity to potato (Lady-Roseta cv.), during summer growing season 2015 and gave high rates of infection to potato plants. In this manner, the isolate which obtained from El-Badrashen (Giza Gov) was the highest aggressive one and causing the highest percentage of stem canker and black scurf. In separate experiments under greenhouse conditions, a number of biocontrol organisms, animal manure extracts and fungicides were evaluated alone in their efficacy to reduce the infection of potato stem canker and black scurf diseases. With regard to bioagents test, Trichoderma harzianum at concentrate $2.0 \%$ improving percentages of eyes germination and reduce dead sprouts of potato and decrease of stem canker and black scurf incidence, compared with Bacillus subtilis and algae treatments. While, animal manure test, Pigeons extract at concentrate $2.0 \%$, gave the highest effect on reducing of stem canker and black scurf incidence compared to Chicken extract. In fungicides experiment, Rizolex (Tolchlophos-methyl) when used before soil inoculation give the best effect in reducing of non-germinated eye, dead sprouts and incidence of stem canker and black scurf compared to Monceren (Pencycuron). On the other hand, the effect of different treatments on the content of potato plants of phenols and oxidative enzymes were studied. In this respect $T$. harzianum, gave the highest content of phenols and activities of oxidative enzymes Peroxidase (PO) and Polyphenoloxidase (PPO).
\end{abstract}

Key words: R. solani, pathogenicity test, biocontrol organisms, animal manures, fungicides and chemical analysis.

\section{INTRODUCTION}

Potato (Solanum tuberosum L.) is one of the most important crops in Egypt as well as all over the world and produces a tuber very rich in starch that it ranks as the world's fourth most paramount food crop, after maize, wheat and rice (Cunnington, 2008). Soil borne diseases are still a major threat to potato cultivation in Egypt (Mohamed, et al., 2013). Rhizoctonia isolates both multinucleate and binucleate species which are divided into anastomosis groups (AGs). Presently, the multinucleate species of $R$. solani Kuhn (teleomorph: Thanatephorus cucumeris (Frank) Donk.) are divided into 14 anastomosis groups (Tuncer and Eken, 
2013): AG-3 is divided into two genetically different subgroups, AG 3 PT associated with potatoes and AG-3 TB on tobacco (Woodhall et al., 2008). Rhizoctonia solani AG-3 PT is an important fungal pathogen that causes both stem canker and black scurf of potato, which lead to tuber yield reduction and losses in tuber quality and it is considered the most destructive disease particularly in warm - climate countries and warm sandy soils of temperate regions (Jager et al., 1996 and Mohamed, et al., 2017). The symptoms of the disease are found on both above and below ground portions of the plant. Black scurf is the most conspicuous sign of Rhizoctonia disease (Almeida et al., 2007). In this phase of the disease the fungus forms dark brown to black hard masses on the surface of the tuber (sclerotia). Formation of tuber-borne sclerotia downgrades tuber quality with the development of malformed (misshapen) tubers and an alteration in target size and number of tubers (Anderson, 1982 and Jager et al., 1996). Stem canker, is the most damaging of the disease as it occurs underground and often goes unnoticed (Grosch et. al., 2005 and Wharton et al., 2006). Early in the season, the fungus attacks germinating sprouts underground before emerging shoots above soil surface. The sprout may be killed outright if lesions form near the growing tip. Damage at this stage results in delayed emergence and is expressed as poor and uneven stands with weakened plants (Wharton et. al., 2006).

Biological control appears to be the best solution for long term sustainability and effective management of soil-borne diseases which can considerably minimize the disease (Howell, 2003). Soil application with $T$. harzianum gave significant protection to potato eyes, sprouts and stolons against soil-borne inoculum of $R$. solani which ultimately contributed to better crop stand and increased yield (Naz, 2006). In field experiments using naturally infested soil and contaminated seed tubers, $T$. harzianum non-pathogenic BNR isolates and cattle manure compost amendment (CMC-H) led to reduced the incidence of black scurf in organically grown potatoes (Tsror et al., 2001). The effect of antagonistic $T$. harzianum on the dynamics of soil-borne $R$. solani on individual potato plants has been recently reported (Wilson et al., 2008). T. harzianum reduced the severity of stem lesion symptoms during the first 7 days post inoculation, but later, the antagonistic effect was overcome. Also the severity of black scurf on progeny tubers was reduced, and there were fewer malformed and green color tubers in pots treated with $T$. harzianum than in the controls. Also, in the present study, some marine algae i.e. S. platensis or $C$. valgaris, during growing season in 2016, summer under greenhouse conditions. Generally, Pratt et al., (1944) reported that Chlorella, there have been several accounts of antimicrobial activity of different species algae. In Egypt, El-Baz et al. (1985) and El-Naggar (1987) studied that antimicrobial activity of some species marine algae or green algae on bacteria and fungi. Likewise, Pesando and Caram (1984) and Moeau et al., (1984) studied the antibacterial and, antifungal propertied of some marine algae from the French Mediterranean coast.

The oxidation products of phenolic compounds appear to be involved in the defence of plants invading pathogens, including fungi, bacteria and viruses, Deborah et al. (2000). On the other hand, chitinlytic enzymes produced by $T$. harzianum have been responsible for the antifungal activity (Lorito et al. 1993). Elad (2000) reported that Trichoderma sp. Are known to produce a number of antibiotics such as Trichodermin, 
Trichodermol, Harzianum A and Harzianolide as well as some cell wall degrading enzymes such as Chitinases, glucanases that break down polysaccharide, chitins and B-glucanase, thereby destroying cell wall integrity. Benitez et al. (2004) demonstrated that Trichoderma strains that overproduce chattiness have been shown to be effective biocontrol agents against pathogens such as Botrytis cinera and $R$. solani.

Compost-amended soils are considered to be suppressive against soil-borne fungi. With matured compost, suppressiveness of $R$. solani was associated with high population densities of cellulolytic and oligotrophic Actinomycetes. The ratio of the Actinomycetes population density to that of other bacteria was around 200-fold higher in mature suppressive compost than in conducive compost (Tuitert et al., 1998). Stimulating populations of mycophagous soil mesofauna with compost can contribute to a reduction in Rhizoctonia disease severity in potato (Scholte and Lootsma, 1998). Moreover, Youssef-Sahar (2007) found that addition of composted chicken manure to sandy soils changed the cultivating to be suppressive to Fusarium wilt of tomato caused by $F$. oxysporum. The presented data suggest that the inhibitory effect of composted chicken manure against soilborne phytopathogens was due to manure biotic and abiotic agents. Investigated the suppressive capability of the compost-peat five mixtures towards the plant pathogens Pythium ultimum, Rhizoctonia. solani and Sclerotinia minor (Pane et al., 2011).

The fungitoxic potential of different anti-R. solani fungicides against AGs is crucial for a successful disease control. Rhizoctonia diseases of potato are controlled by seed tuber or soil treatments, in this respect only pencycuron and tolclofos-methyl afforded $100 \%$ inhibition of AG-3 in vitro, whereas in the field, azoxystrobin and pencycuron showed the highest efficacy against sclerotial development on tubers (Virgen-Calleros et al., 2000). Hausvater and Trnkova (1993) reported that pencycuron (Monceren 250, FS) gave the best control against $R$. solani disease the other tested chemicals. The effects were similar in most cases to those of Rizolex fungicide, which increased emergence, chlorophyll content of potato leaf, potato tuber yield and reduced black scurf and dry rot severity El-kot (2008).

\section{MATERIALS AND METHODS}

\section{Isolation, purification and Identification of the causal pathogen: \\ Potato plants showing symptoms of} Rhizoctonia disease were collected from 8 fields in major potato growing governorates, i.e Ismailia (El-Kassasen), Gharbia (Kafer El-zayat), Minofya (ElKatatba), Giza (El-Badrashen), Minia (Behdal), Behera (Housh-Essa), Assiut (Dairoot) and Sohag (Shandaweel) during growing season 2015.

\section{1. Isolation of $R$. solani from root and stem cankers of potato plants}

Infected basal stems, root cankers and tubers were wished thoroughly with tap water. Pieces of tissues from the margins of lesions on infected stems and stolon's were cut into small (1cm long) pieces, surface sterilized by immersing in sodium hypochloride (1\%) for three minutes, (Carling and Leiner, 1990a and Yanar et al., 2005), rinsed several times in sterilized distilled water, and dried between two sterilized filter papers. Three pieces were arranged onto potato dextrose agar (PDA) supplemented with streptomycin sulfate $(40 \mathrm{mg} / 100 \mathrm{ml})$. Petri dishes were incubated at $25^{\circ} \mathrm{C}$ and have been examined daily and the fungal 
growth originating from each segment was cultured to obtain a pure culture.

\section{2. Isolation of $R$. solani from sclerotia on tuber}

Samples of tubers (different cultivars), showing symptoms of black scurf, were collected from the previous mentioned governorates. Tubers were thoroughly washed under running water to remove adhering soil particles. Small pieces of tubers with sclerotia were surfacedisinfected in sodium hypochlorite solution (1\%) for 2 minutes, sclerotia were then removed from each tuber, then rinsed in sterile tap water, and allowed to air-dry on a laminar-flow bench (Malik et al., 2014). A minimum of four sclerotia were plated on PDA medium supplemented with streptomycin sulfate (40mg/100 ml medium).

\subsection{Purification of $R$. solani}

The typical growth of the hyphae includes branching near the distal septum of the cells, constriction of hyphae and formation of septa in a short distance from the origin of the hyphal branching as described by Sneh et al. (1991) was isolated in pure culture. Petri dishes containing about $10 \mathrm{ml}$ potato dextrose agar (PDA) medium/plate. The plates were inoculated at $24 \pm 2^{\circ} \mathrm{C}$ until mycelial growth developed and hyphal tips were then transferred to PDA slants Papavizas and Davey (1959). Five isolates of the causal pathogen, $R$. solani, were isolated by potato dextrose agar (PDA) medium/plate. Hyphal tip of the developing fungus was transferred to PDA to obtain pure cultures, examined microscopically.

\subsection{Identification of $R$. solani}

The identification of the isolated fungus was carried out using characteristics of the mycelia as described by Gilman (1957), Barnett and Hunter (1972) and using the key adopted by Sneh et al (1991). Stock cultures were maintained on PDA slant and stored in refrigerator at $5^{\circ} \mathrm{C}$ for further studies.

Isolates of Rhizoctonia were assigned to an anastomosis group by pairing the isolates with tester strains and observing the hyphae for fusion. The clean slide technique for the observation of anastomosis of $R$. solani was used in this study. The tester isolates were kindly given Plant Pathology Department, National Research Center, Giza, Egypt. Each isolate was paired with the tester isolate of each AG on $2 \%$ water agarcoated slide with two replicates in Petri dishes (Windels and Nabben, 1989). Discs of mycelium from the margins of unknown isolate and an appropriate tester strain were placed on the slide approximately 2-3 cm apart in the 9-cm Petri dishes. After that the plates were incubated at $25^{\circ} \mathrm{C}$ in the dark until advancing hyphae made contact and slightly overlapped. About $2-3 \mathrm{~cm}^{2}$ in the area of contact with $0.001 \%(w / v)$ cotton blue in diluted lactophenol stain and scanned for hyphal fusion at $400 x b y$ microscopic inspection (Carling and Leiner, 1986). Individual hyphae were often traced back to ensure that anastomosis was made between the paired isolates and not between branches of the same isolate. The hyphal fusion dissolution of fused and walls, and the advent of hyphal protoplasm (anastomosis) were observed between the tester isolates and all the obtained isolate belonging to $R$. solani.

\section{Pathogenicity test:}

The ability of five $R$. solani, isolates were isolated from naturally infected potato plants Lady-Roseta cv. obtained from different localities in Egypt, i.e. Ismailia (El-Kassasen), Gharbia (Kafer Elzayat), Minofya (El-Khatatba) Giza (ElBadrashen), and Minia (Behdal), during growing season in 2015, summer under greenhouse conditions to determine the 
pathogenic properties of the tested isolates. Inocula of $R$. solani were prepared on autoclaved barley medium in $500 \mathrm{ml}$ glass bottles $(75 \mathrm{~g}$ washed dried barley grains; $100 \mathrm{~g}$ washed dried coarse sand and $75 \mathrm{ml}$ tap water). Each bottle was inoculated with a disc $(5 \mathrm{~mm}$ in diam.), taken from the margin of a one week-old culture of the isolates grown on PDA medium. The bottles were then incubated at $25^{\circ} \mathrm{C}$ in the dark for two weeks. Clay-sand soil (4:1 w/w), was sterilized with autoclaved for $\mathbf{4 0}$ minutes, sterilization of pots was carried out by using $5 \%$ formaldehyde solution and compacted into plants pots $(50 \mathrm{~cm}$ in diam.), each pot containing $7 \mathrm{~kg}$ sterilized clay-sandy soil. The content of bottles was thoroughly mixed in plastic container and used as a source of inoculum. Inoculum of each isolate of pathogen was added to the soil in pots at a rate of $1 \%(w / w)$ one week before sowing (1g. inoculum/100g. soil), mixed well and thoroughly irrigated. Two sets of pots were used, in the first set inoculation was carried one week prior to planting, but in the another set, pots were inoculated by adding and incorporating inoculum 30 days after planting.

The tubers were placed in the dark at room temperature until sprouted (13-15 days). Potato tubers were cut into pieces and were left for $\mathbf{4 8}$ hrs before planting. In each pot, two pieces of potato tubers having 3 eyes of almost same size were arranged in the pot $5-7 \mathrm{~cm}$ below the soil surface and covered with soil and watered weekly as required (Naz, 2006). Pots containing soil mixed with $1 \%$ barley grain medium free of the fungus were used as control.

The disease incidence was evaluated by four parameters; percent of inhibition in eyes germination (eyes germination inhibition; EGI) and killing sprouts (KS) were taken one month after sowing by harvesting one set of experiment, whereas, the percentages of stem canker (SCS) and black scurf severity (BSS) were recorded when plants showed signs of maturity, 90 days after sowing by harvesting the second set of experiment as described by Rauf et al. (2007-a). All pots were kept under careful observations in greenhouse in natural light of Mallawy Agricultural Research Station, RAC. Percentages of EGI and SK were calculated as mentioned by Naz, et al., (2008) as following:

1-Eyes germination (EGI, \%) = Number of non-germinated eyes $\times 100$ Total number of eyes

Eyes germination inhibition \%= 100- EGI, \%

2- Killing sprouts $(\mathrm{KS}, \%)=$

Number of sprouts killed in each treatment x100 Total number of sprouts

- Stem canker severity was expressed as stem canker index (SCl). Severity was assessed on a 0-4 visual disease rating scale as described by Carling and Leiner (1990 b) using the following formula:

3- Stem canker \% (SCl, \%) =

Number of stems in each rating $x$ rating $\times 100$ Total number of stems

Whereas: $0=$ no damage, no lesions; $1=$ minor damage, one to several lesions less than $5 \mathrm{~mm}$ long; 2=intermediate damage, lesions longer than $5 \mathrm{~mm}$, girdling of some tissue; $3=$ major damage, large, lesions, girdling and death of most tissue and 4= all tissue dead.

- Black scurf severity was determined by using 0-5 disease severity grades based on percent tuber surface showing disease symptoms (Malik et al., 2014).

4- Black scurf disease (BSI, $\%)=$ $\underline{0}\left(\mathrm{n}_{1}\right)+1\left(\mathrm{n}_{2}\right)+2\left(\mathrm{n}_{3}\right)+3\left(\mathrm{n}_{4}\right)+4\left(\mathrm{n}_{\underline{5}}\right)+5\left(\mathrm{n}_{\underline{6}}\right) \times 100$ $\mathrm{N}$ (Total number of tubers) $\times 6$

Whereas: $n_{1}$ to $n_{6}=$ number of tubers in $0-5$ grades, $0=$ no symptoms on potato tubers; 1= less than 1\% tuber area affected; 2=1-10\% tuber area affected; 
M.A. Khalil, et al.,

$3=11-20 \%$ tuber area affected; $4=21-51 \%$ tuber area affected and $5=51 \%$ or more of tuber area affected.

\section{Effect of biocontrol organisms,} animal manure extracts, and fungicides on controlling potato stem canker and black scurf disease under greenhouse conditions:

3.1. Effect of soil treatment with bioagents, on controlling Rhizoctonia disease of potato

Evaluation of integrated bioagent, $T$. harzianum and $B$. subtilis or marine algae extracts, Spiruliua platensis or Chlorella valgaris against stem canker and black scurf disease cause by the highly virulent isolate of $R$. solani Giza (EIBadrashen), on potato (Lady-Roseta cv.) at concentrations 0.5 and $2.0 \%$, during growing season in 2016, summer under greenhouse conditions. Each $T$. harzianum and $B$. subtilis were obtained from Plant Pathology, Res. Inst. Agriculture Research Center. An isolates of each $T$. harzianum and $B$. subtilis were purified on PDA media. Trichoderma isolate were identified according to their morphological and microscopic characteristic Domsch et al. (1980) and confirmed by Assiut University, Mycological Center (AUMC) Faculty of Science. Whereas bacteria was identified according to Burbage et al. (1982). Firstly, soil was infested with the pathogenic fungus in different pots. The inoculum $T$. harzianum, was prepared by growing in $1000 \mathrm{ml}$ conical flasks each containing $250 \mathrm{ml}$ vermiculate, $250 \mathrm{ml}$ Czapeks liquid medium (vol/vol) and autoclaved for 20 minutes at $121^{\circ} \mathrm{C}$, on two consecutive days. The flasks were inoculated with the $T$. harzianum, and inoculated at $25^{\circ} \mathrm{C}$ for 25 days. After 25 day's incubation period, contents of flasks were transferred to plastic plates under sterile conditions; left to dry then mixed in a blender to become powder and calculated the inoculum density in 1 gm formula by using serial dilutions $T$. harzianum, mixtures contain $15.9 \times 10^{7}$ CFU/gm formula and kept in polyethylene bags at room temperature until used. The formulated antagonists were added to previously infested soil with $R$. solani most virulent isolate (at the rate of 1 and $2 \%(w / w)$ two weeks before planting. Tuber seeds were sown in infested soil as control. Next, bacterial isolate of $B$. subtilis consisted of aqueous solutions prepared from 3-day-old cultures of bacteria grown on PD broth media. One week after soil infestation with the pathogen, pre-sprouted potato seed tubers were soaked for 2 hours in aqueous solutions of the bacterial suspension, contained $10^{7} \mathrm{cful} \mathrm{ml}$, to be tested and immediately were sown. Some marine algae i.e. S. platensis or $C$. valgaris, obtained from Unit of Algae, National Research Center, Giza, Egypt, that were washed from sand and foreign materials with sea water. Some of the fresh materials were stored frozen at$20^{\circ} \mathrm{C}$ and the rest were air dried in the shade. One week after soil infestation with the pathogen, algae extracts as soil drench at concentrations 0.5 and $2.0 \%$. The pots were irrigated for 7 days before bio-control fungal agent's inoculation. Distilled water free of antagonistic agent was used for treating control. Four pots from each treatment were used as four replicates. Percentage of eyes germination and death of emerging sprouts were recorded at 21 and $\mathbf{4 5}$ days after sowing, respectively, while percentage of stem canker and black scurf were recorded when plants showed signs of maturity after about three months from sowing.

\subsection{Effect of animal manure extracts infection with $R$. solani \\ Animal manure (Chicken and Pigeons) extracts, was prepared according to the seepages procedures of El-Masry et al.,}


2002. Composted manures were mixed with tap water (1:5 vol/vol) in large containers. The suspension was inoculated for 6 days at 15 to $20^{\circ} \mathrm{C}$ and daily stirred 5 to 10 minutes. After extraction, the mixtures was filtrated through 3 layers of cheesecloth and centrifuged for 60 minutes at $3000 \mathrm{rpm}$. The filtrates were then sterilized by Seitz filter and stored at $4^{\circ} \mathrm{C}$ for further studies. The animal manures (Chicken and Pigeons) obtained from Minia governorate evaluated on the most virulent isolate, Giza (El-Badrashen, No 4). The study conducted during the season 2016 under greenhouse conditions of Mallawy Research station, ARC. Animal manures at the rate 0.5, 1.0 and $2.0 \%(5,10$ and $20 \mathrm{gm} / \mathrm{kg}$ soil) of each of the tested manure (Raj and Kapoor, 1997) were added to the sterilized clay-sand soil two weeks before sowing mixed thoroughly and irrigated. Inoculum of pathogen isolate was added to the soil in pots at the rate of $1 \%(w / w)$ one week before sowing. Tuber seeds of potato (Lady-Roseta cv.) were sown in pots containing infested soil with the pathogen isolate. Four pots from each treatment were used as four replicates. Pots containing infested soil with the tested isolate of pathogen were sown with tuber seeds and that contain non-infested soil and sown with tuber seeds were served as control. Diseased assessed, i.e. EGI\%, $\mathrm{Ks} \%$, SCI \% and BSI were recorded as mentioned before.

\subsection{Evaluation of some fungicides for} controlling of stem canker and black scurf disease

Pot experiment was carried out to study the efficiency of some recommended fungicides, i.e., Rizolex $50 \%$ WP (Tolchlophos - methyl) and Monceren 25\%WP (Pencycuron) were tested against stem canker and black scurf of potato under greenhouse condition in 2016. Fungicides were added to previously infested soil with the most pathogenic isolate of $R$. solani (No.4), at the rate of $1 \mathrm{~g} / 100 \mathrm{~g}$ of soil and $2 \%(\mathrm{w} / \mathrm{w})$ two weeks before and after inoculation with the pathogenic fungus. Tuber pieces of (cv. Lady-Rositta) potato were sown in $50 \mathrm{~cm}$ diameter pots containing infested soil by the most pathogenic isolate of $R$. solani. Four pots were devoted for each fungicide. One week after soil infestation with the pathogenic fungus, at the rate of $1 \mathrm{~g} / 100 \mathrm{~g}$ of soil and $2 \%$ (w/w), presprouted potato seed tubers were treated before and after inoculation with two fungicides. Fungicides combinations used to treat seeds tubers. Pots containing sterilized non- infested soil were sown with tuber seeds and served as control treatment tubers had no fungicide application Data recorded as mentioned before.

\section{Determination of the phenolic compounds content:}

Free, total phenols and conjugated were colourimetrically determined using the "Folin and Ciocaltei" reagent as described by Snell and Snell (1953).The reagent was prepared by Folin-ciocalteu reagent: $100 \mathrm{gms}$ of sodium tungstate, $25 \mathrm{mg}$ of sodium molybdate, $700 \mathrm{ml}$ of distilled water $50 \mathrm{ml}$ of $58 \%$ phosphoric acid and $100 \mathrm{ml}$. of concentrated hydrochloric acid (HCL) were boiled under reflux condenser for $10 \mathrm{hr}$, then $150 \mathrm{gms}$, of lithium sulphate, $50 \mathrm{ml}$ of distilled water and few drops of liquid bromine were added. To remove excess bromine, the mixture was boiled for $10 \mathrm{~min}$, then cooled and diluted to one liter. Free, total phenols and conjugated were determined in extracts of infected and healthy cucumber plants. Determination was calculated as catechol in terms of $\mathrm{mg}$ phenols per $1 \mathrm{~g}$ dry weight of stem-base.

\subsection{Total phenolic compounds determination}


Total phenols content was estimated by adding 10 drops of concentrated $\mathrm{HCL}$ to $0.05 \mathrm{ml}$ of the extract and boiled rapidly in a boiling water bath for $10 \mathrm{~min}$. After cooling, $1.0 \mathrm{ml}$ of Folin-ciocalteu reagent and $5 \mathrm{ml}$ of $20 \% \mathrm{Na}_{2} \mathrm{CO}_{3}$ were added. The mixture was diluted to $10 \mathrm{ml}$ using warm distilled water $\left(30-35^{\circ} \mathrm{C}\right)$. After $30 \mathrm{~min}$, the developed colour was determined at $520 \mathrm{~nm}$ using a spectrophotometer. A standard curve from a pure chemical of catechol was used.

\subsection{Free phenolic compounds determination}

Free phenols were estimated by adding $5 \mathrm{ml}$ of Folin-ciocalteu reagent and $5 \mathrm{ml}$ of sodium carbonate $(20 \%)$. The mixture was completed to $50 \mathrm{ml}$ with warm distilled water $\left(30-35^{\circ} \mathrm{C}\right)$, then thoroughly mixed and left to stand for 20 min. The developed colour was determined at $520 \mathrm{~nm}$ using a spectrophotometer.

\subsection{Conjugated phenolic compounds determination}

The conjugated phenols content was estimated by subtracting the free phenols from the total ones.

\section{Determination of oxidative enzymes:}

The oxidative enzymes to determine peroxidase and polyphenol oxidase activity in stem of potato inoculated separately with isolate of $R$. solani, Giza (El-badrashen). The enzyme extraction from all samples was prepared as recommended by Maxwell and Bateman (1967). The samples were ground with 0.1 M. sodium phosphate buffer at pH 7.1 (2 $\mathrm{ml}$ buffer/g tissue), in a mortar. These tissues were strained through four layers of cheesecloth and the filtrates were centrifuged at $3000 \mathrm{rpm}$ for $20 \mathrm{~min}$. at $6^{\circ} \mathrm{C}$. The supernatant fluid was used for enzyme assays. Peroxidase and polyphenol oxidase assays were determined using a spectrophotometer (model 601). The blank cuvette always contained the same concentration of component as the sample corvette, except that the substance solution was replaced by distilled water. The Spectrophotometer corvettes were thoroughly mixed, and the optical density was recorded every $30 \mathrm{sec}$. for $3 \mathrm{~min}$. in case of peroxidase and polyphenol oxidase activity.

\subsection{Peroxidase assay}

Peroxidase enzymes were estimated according to the method of Allam and Hollis (1972) by measuring the oxidation of pyrogallol in pyrogallin in the presence of $\mathrm{H}_{2} \mathrm{O}_{2}$ at $425 \mathrm{~nm}$. The sample corvette was contained $0.5 \mathrm{ml}$ of $0.1 \mathrm{M}$ potassium phosphate buffer (pH 7), $0.1 \mathrm{ml}$ enzymes extract, and $0.3 \mathrm{ml}$ of pyrogallol and 0.1 $\mathrm{ml} \% \mathrm{H}_{2} \mathrm{O}_{2}$, brought to $3 \mathrm{ml}$ with distilled water.

\subsection{Polyphenol oxidase assay}

The activity of polyphenol oxidase was measured using the colorimetric method of Maxwell and Bateman (1967). The reaction mixture contained $0.2 \mathrm{ml}$ enzyme extract, $0.5 \mathrm{ml}$ sodium phosphate buffer at pH 7 and $0.5 \mathrm{ml}$ of catechol and brought to a final volume of $3.0 \mathrm{ml}$ with distilled water. The activity of polyphenol oxidase was expressed as the change in absorbance $\mathrm{ml}$ of extract per min at 495 nm.

\section{Statistical analysis}

All trials used a randomized complete block design with four replicates. The obtained data were subjected to statistical analysis using MSTAT computer program (Michigan Statistical Program Version $C$ ). Least significant difference (L.S.D., $p=0.05$ ) for comparison between means of treatments was used as mentioned by Gomez and Gomez (1984). 


\section{Experimental Results}

1. Isolation, purification and identification of the causal pathogen:

Eight isolates (Table 1) were isolated from diseased plants, showing stem and root cankers, sprouts and tubers with sclerotia. The culture microscopic studies revealed that all isolates fitted well as $R$. solani. The typical growth of the hyphae includes branching near the distal septum of the cells, constriction of hyphae and formation of septa in a short distance from the origin of the hyphal branching. Isolation from diseased potato plants showing the aforementioned symptoms of stem canker and black scurf. Eight isolates of $R$. solani were tested for their ability to anastomosis with a tester isolate (AG-3), by using the clean slide technique by another research, which were isolated from Ismailia (El-Kassasen, No 1), Gharbia (Kafer El-zayat, No 2), Minofya (El-Khatatba, No 3) Giza (El-Badrashen, No 4) and Minia (Behdal, No 5) fused perfectly with the tester isolate (AG-3). While the isolates of $R$. solani which were isolated from, Behera (Housh-Essa, No 6), Assiut (Dairoot, No 7) and Sohag
(Shandaweel, No 8) showed that no anastomosis reaction was observed between them and the tester isolates (AG3). Hyphal fusion at minimum of five points was considered to be positive indication according to Parameter, et al., (1969).

Also, data in Table (2) indicate that the obtained isolates differed in the culture color, number of sclerotia/plate and the size of sclerotia. The isolates were classified according to their color of different cultures differed from brown and yellow, while sclerotia size the differed from large $(5.5 \mathrm{~mm})$, moderate (2$2.5 \mathrm{~mm}$ ), small (1.5) $\mathrm{mm}$ ) and two isolates did not form sclerotia on the medium. Identification of fungal isolates was carried out according to their morphological characteristics of mycelia. The typical growth of the hyphae includes branching near the distal septum of the cells, constriction of hyphae and formation of septa in a short distance from the origin of the hyphal branching as described by Sneh et al., (1991) and confirmed by Assiut University Mycological Center (AUMC), Faculty of Science.

Table (1): Identification of the obtained isolates using anastomosis test

\begin{tabular}{|c|c|c|c|}
\hline Governorate & Isolate locality & $\begin{array}{c}\text { Anastomosis group } \\
\text { AG-3 }\end{array}$ & Isolate No. \\
\hline Ismailia & El-Kassasen & + & 2 \\
\hline Gharbia & Kafer El-zayat & + & 3 \\
\hline Minofya & El-Khatatba & + & 4 \\
\hline Giza & El-Badrashen & + & 5 \\
\hline Minia & Behdal & - & 6 \\
\hline Behera & Housh-Essa & - & 7 \\
\hline Assiut & Dairoot & - & 8 \\
\hline Sohag & Shandaweel & + & 2 \\
\hline
\end{tabular}

This test was carried out between a tester isolate (AG-3) and hypha of the some isolates AGs collected from different governorates. 
M.A. Khalil, et al.,

Table (2): Differences between isolates of. $R$. solani in culture color, number and size of sclerotia on PDA medium

\begin{tabular}{|c|c|c|c|c|c|}
\hline $\begin{array}{c}\text { Isolate } \\
\text { No. }\end{array}$ & Governorate & Isolate locality & Culture color & $\begin{array}{c}\text { No. of } \\
\text { sclerotia/plate }\end{array}$ & $\begin{array}{c}\text { Mean size of sclerotia } \\
\text { mm }\end{array}$ \\
\hline 1 & Ismailia & El-Kassasen & Brown & 18 & 2.5 \\
\hline 2 & Gharbia & Kafer El-zayat & Brown & 15 & 2 \\
\hline 3 & Minofya & El-Khatatba & Brown & 10 & 5.5 \\
\hline 4 & Giza & El-Badrashen & Brown & 35 & 2.5 \\
\hline 5 & Minia & Behdal & Brown & 22 & 1.5 \\
\hline 6 & Behera & Housh-Essa & Yellow & 8 & - \\
\hline 7 & Assiut & Dairoot & Yellow & - & - \\
\hline 8 & Sohag & Shandaweel & Yellow & - & 2.5 \\
\hline
\end{tabular}

\section{Pathogenicity test:}

Pathogenic capability of five isolates of $R$. solani, №. 1, №. 2, №. 3, №. 4 and, No 5, were tested. Data presented in Table (3) indicate that all $R$. solani isolates were able to infect Lady-Roseta cv., causing typical symptoms of stem canker and black scurf disease. The five tested isolates deeply varied in their ability to cause stem canker and black scurf disease. The isolate №. 4 which obtained from Giza was the highest aggressive one causing the highest percentage of stem canker and black scurf being, $(80.88,77.63 \%)$ respectively, followed by the isolate No. 5 (Minia). While, Isolates №.1 \&2, were moderately aggressive (25-35\%). However, isolate №. 3 was the least one in their aggressiveness.

Data in Table (3) also indicate that, all tested isolates of $R$. solani capable to inhibit the germination of eyes and developed sprouts with different degrees of infection. The isolate №. 4 which obtained from Giza give the highest percentage of non-germinated eyes and death of emerging sprouts $\mathbf{( 5 0 . 0 0 \text { , }}$ $59.16 \%$ ) respectively, followed by the isolate №.5. While the isolates №.1\&2, give a moderate effect. However, isolate No. 3 was the least one in their effect on eyes germinated and emerging sprouts.

3. Effect of the biocontrol organisms, animal manure extracts and fungicides on controlling of potato stem canker and black scurf disease under greenhouse conditions:

\subsection{Effect of soil treatment with biocontrol agents}

Results presented in Table (4) revealed that, the individual addition of biocontrol organisms, T. harzianum and $B$. subtilis and marine algae extracts, $S$. platensis or $C$. valgaris, to the soil before sowing significantly decrease the dead sprouts under greenhouse conditions during season 2016. Data also show that all tested treatment at the concentrations of 0.5 and $2.0 \%$ were effective in reducing the percentage of ungermination eyes, dead sprouts and increased survival plants as well as improved plant growth characters compared to the control. Generally, the best control of the disease recorded by $T$. harzianum treatment 
followed by $B$. subtilis and $S$. platensis. While, $C$. valgaris, gave the lowest effect in controlling dead sprouts disease. In $T$. harzianum treatment, the disease incidence was reduced to the17.86 and $12.50 \%$ with the most virulent isolate. Data also indicate that addition of the biocontrol organisms, to the soil before sowing influenced significantly decrease in stem canker and black scurf.
Generally, T. harzianum, caused the highest effect on the disease incidence and gave the best control of the disease at the concentration of $2.0 \%$ and reduced the disease to 19.12 and $15.68 \%$ followed by $B$. subtilis and $S$. platensis. While, $C$. valgaris, give the lowest effect in controlling stem canker and black scurf diseases at the concentration of (2.0\%).

Table (3): Pathogenicity test of $R$. solani isolates on potato Lady-Roseta cv. under greenhouse conditions during 2015 season

\begin{tabular}{|c|c|c|c|c|c|}
\hline \multirow{2}{*}{$\begin{array}{l}\text { Isolate } \\
\text { No. }\end{array}$} & \multirow[b]{2}{*}{ Governorate } & \multicolumn{4}{|c|}{ Disease parameter } \\
\hline & & $\begin{array}{l}\text { Ungerminated } \\
\text { eyes } \%\end{array}$ & $\begin{array}{c}\text { Dead sprouts } \\
\%\end{array}$ & $\begin{array}{c}\text { Stem canker } \\
\%\end{array}$ & $\begin{array}{c}\text { Black } \\
\text { scurf \% }\end{array}$ \\
\hline 1 & Ismailia & 32.15 & 43.73 & 44.12 & 42.11 \\
\hline 2 & Gharbia & 17.86 & 33.33 & 35.30 & 39.48 \\
\hline 3 & Minofiya & 14.29 & 14.58 & 23.53 & 22.37 \\
\hline 4 & Giza & 50.00 & 59.16 & 80.88 & 77.63 \\
\hline 5 & Minia & 39.29 & 46.67 & 72.06 & 56.58 \\
\hline \multicolumn{2}{|c|}{ Control } & 0.00 & 0.00 & 0.00 & 0.00 \\
\hline \multicolumn{2}{|c|}{ L.S.D. at $0.05 \%$} & 13.73 & 10.54 & 7.16 & 8.52 \\
\hline
\end{tabular}

Table (4): Effect of some biocontrol organisms in controlling potato stem canker and black scurf diseases under greenhouse conditions during 2016 season

\begin{tabular}{|c|c|c|c|c|c|}
\hline \multirow{2}{*}{ Bioagent } & \multirow{2}{*}{ Concentration\% } & \multicolumn{4}{|c|}{ Disease parameter } \\
\hline & & $\begin{array}{l}\text { Ungerminated } \\
\text { eyes } \%\end{array}$ & $\begin{array}{c}\text { Dead sprouts } \\
\%\end{array}$ & Stem canker \% & Black scurf \% \\
\hline \multirow{2}{*}{ T.harzianum } & 0.5 & 31.46 & 27.08 & 33.82 & 27.58 \\
\hline & 2.0 & 17.86 & 12.50 & 19.12 & 15.68 \\
\hline \multirow{2}{*}{ B. subtilis } & 0.5 & 40.48 & 31.25 & 31.24 & 31.53 \\
\hline & 2.0 & 29.21 & 16.67 & 23.53 & 21.27 \\
\hline \multirow{2}{*}{ S. platensis } & 0.5 & 46.92 & 37.50 & 36.77 & 35.43 \\
\hline & 2.0 & 33.82 & 33.33 & 25.00 & 25.00 \\
\hline \multirow{2}{*}{ C. valgaris } & 0.5 & 50.01 & 46.67 & 39.71 & 43.94 \\
\hline & 2.0 & 55.95 & 41.67 & 32.09 & 28.90 \\
\hline \multicolumn{2}{|c|}{ Control } & 91.18 & 86.11 & 82.84 & 80.56 \\
\hline \multicolumn{2}{|c|}{ L.S.D. at $0.05 \%$} & $\begin{array}{c}T=6.65 \quad C-5.76 \\
T \times C=11.49\end{array}$ & $\begin{array}{c}\mathrm{T}=3.5 \quad \mathrm{C}-3.0 \\
\mathrm{TXC}=6.20\end{array}$ & $\begin{array}{c}\mathrm{T}=5.62 \quad \mathrm{C}-5.80 \\
\mathrm{~T} \times \mathrm{C}=9.72\end{array}$ & $\begin{array}{c}\mathrm{T}=3.41 \quad \mathrm{C}-2.90 \\
\mathrm{~T} \times \mathrm{C}=5.90\end{array}$ \\
\hline
\end{tabular}


M.A. Khalil, et al.,

\subsection{Effect of animal manure extracts on infection with $R$. solani}

The presented data in Table (5) indicate that, individual addition of animal manure (Chicken and Pigeons) extracts, at concentrations of $0.5,1.0$ and $2.0 \%$ to the soil infested with the most virulent isolate of $R$. solani (No.4) before sowing significantly increase of eyes germination, decreased dead sprouts and increased survival plants as well as improved plant growth under greenhouse conditions compared to the control during season 2016. Generally, Pigeons manure at the concentration of $2.0 \%$ caused the highest effect on the reduction of ungermination eyes and dead sprouts (14.29 and 8.33\%), compared to Chicken manures (22.28, $36.63 \%)$ respectively. At the same time, the seedlings were very strong compared to the control. On the other hand, data indicate that, addition of animal manure (Chicken and Pigeons) extracts, to the soil before sowing significantly reduction the stem canker and black scurf. Generally, Pigeons manure caused the highest effect on the disease incidence at the concentration of $2.0 \%$ (19.12 and $14.48 \%$ ) compared to Chicken manures (41.18,17.11\%), respectively.

3.3. Efficacy of some fungicides in controlling $R$. solani on potato under greenhouse conditions

Results presented in Table (6) indicate that, addition Rizolex $50 \%$ WP (Tolchlophos-methyl) and Monceren 25\%WP (Pencycuron) to the soil before and after sowing significantly increment of eye germination percentage, reduced dead sprouts and increased survival plants as well as improved plant growth characters compared to the control. Generally, Rizolex 50\% WP (Tolchlophosmethyl) caused the highest effect on the disease control when added before inoculation where it decreased of ungerminated eyes and dead sprouts. Data also reveal that application of Rizolex 50\% WP before inoculation, proved more powerful in decreasing diseases severity with stem canker and black scurf compared to the control.

4. Effect of the causal organism on some constituents of Lady-Roseta cv. potato plants:

4.1. Free conjugated and total phenol contents of potato (Lady-Roseta cv.) sown in the infested soil with the highly virulent isolate of $R$. solani

Data in Table (7) show that, individual treatment, with Rizolex 50\% WP (Tolchlophos-methyl), Pigeons manure, S. platensis B. subtilis and T. harzianum, after sowing in the infested soil increased the levels of phenols content in comparison with the control. In this respect, $T$. harzianum treatment, showed the higher levels of phenols content in the inoculated potato plants compared to other treatments as well as the noninoculated plants (control).

\subsection{Determination of oxidative enzyme contents of potato (Lady-Roseta cv.) sown in the infested soil with the highly virulent isolate of $R$. solani}

Results presented in Table (8) indicate that, individual application of Rizolex $50 \%$ WP, Pigeons manure, S. platensis B. subtilis and $T$. harzianum, after sowing in the infested soil give impact on the enzymes activity of Peroxidase $(\mathrm{PO})$ and Polyphenoloxidase (PPO). In this regard, treated Lady-Roseta Cv. potato plants by $T$. harzianum, give the higher activity of Peroxidase (PO) and Polyphenoloxidase (PPO) in inoculated potato plants compared to other treatments as well as the non-inoculated plants (control). 
Table (5): Effect of animal manure extracts on controlling potato stem canker and black scurf disease under greenhouse conditions

\begin{tabular}{|c|c|c|c|c|c|}
\hline \multirow{2}{*}{$\begin{array}{c}\text { Source of } \\
\text { manure }\end{array}$} & \multirow[b]{2}{*}{ Concentration \% } & \multicolumn{4}{|c|}{ Disease parameter } \\
\hline & & $\begin{array}{l}\text { Ungerminat } \\
\text { ed eye\% }\end{array}$ & $\begin{array}{l}\text { Dead } \\
\text { sprout\% }\end{array}$ & $\begin{array}{c}\text { Stem } \\
\text { canker\% }\end{array}$ & $\begin{array}{l}\text { Black } \\
\text { scurf\% }\end{array}$ \\
\hline \multirow{3}{*}{ Pigeons } & 0.5 & 35.02 & 30.21 & 38.24 & 46.00 \\
\hline & 1.0 & 25.85 & 23.91 & 29.41 & 23.69 \\
\hline & 2.0 & 14.29 & 8.33 & 19.12 & 14.48 \\
\hline \multirow{3}{*}{ Chicken } & 0.5 & 58.34 & 50.08 & 69.12 & 57.96 \\
\hline & 1.0 & 48.11 & 41.20 & 45.59 & 18.42 \\
\hline & 2.0 & 22.28 & 36.63 & 41.18 & 17.11 \\
\hline \multicolumn{2}{|r|}{ Control } & 100.00 & 83.34 & 77.94 & 68.42 \\
\hline \multicolumn{2}{|r|}{ Mean } & 43.41 & 39.1 & 45.8 & 35.15 \\
\hline \multicolumn{2}{|c|}{ L.S.D. at $0.05 \%$} & $\begin{aligned} T & =4.93 \\
C & =6.98 \\
T \times C & =9.87\end{aligned}$ & $\begin{aligned} T & =6.07 \\
C & =8.58 \\
T \times C & =12.12\end{aligned}$ & $\begin{array}{c}T=4.35 \\
\mathrm{C}=6.16 \\
\mathrm{TxC}=8.73\end{array}$ & $\begin{array}{c}T=4.76 \\
C=6.69 \\
T x C=9.49\end{array}$ \\
\hline
\end{tabular}

Table (6): Effected Rizolex 50\% WP and Monceren 25\%WP fungicides on controlling potato stem canker and black scurf disease

\begin{tabular}{|c|c|c|c|c|c|c|c|c|}
\hline \multirow{3}{*}{ Fungicide } & \multicolumn{8}{|c|}{ Disease parameter } \\
\hline & \multicolumn{2}{|c|}{ Ungerminatedeye\% } & \multicolumn{2}{|c|}{ Dead sprouts\% } & \multicolumn{2}{|c|}{ Stem canker\% } & \multicolumn{2}{|c|}{ Black scurf\% } \\
\hline & \begin{tabular}{|c|} 
After \\
inoculation
\end{tabular} & $\begin{array}{c}\text { Before } \\
\text { inoculation }\end{array}$ & $\begin{array}{c}\text { After } \\
\text { inoculation }\end{array}$ & \begin{tabular}{|c|} 
Before \\
inoculation
\end{tabular} & $\begin{array}{c}\text { After } \\
\text { inoculation }\end{array}$ & \begin{tabular}{|c|} 
Before \\
inoculation
\end{tabular} & $\begin{array}{c}\text { After } \\
\text { inoculation }\end{array}$ & $\begin{array}{c}\text { Before } \\
\text { inoculation }\end{array}$ \\
\hline $\begin{array}{l}\text { Rizolex } \\
50 \% \text { WP }\end{array}$ & 21.43 & 17.86 & 16.67 & 10.42 & 17.65 & 14.71 & 18.42 & 15.79 \\
\hline \begin{tabular}{c|}
$\begin{array}{c}\text { Monceren } \\
25 \% W P\end{array}$ \\
\end{tabular} & 25.00 & 14.29 & 29.17 & 22.92 & 33.82 & 23.53 & 38.11 & 31.58 \\
\hline Control & 89.29 & 82.14 & 93.75 & 50.00 & 82.35 & 72.06 & 85.52 & 77.63 \\
\hline Mean & 45.24 & 38.01 & 46.53 & 27.78 & 44.61 & 36.77 & 47.35 & 41.67 \\
\hline $\begin{array}{c}\text { L.S.D. at } \\
0.05 \%\end{array}$ & $\mathrm{~T}=18.89$ & $C=11.66$ & $\mathrm{~T}=5.36$ & $C=10.48$ & $\mathrm{~T}=7.40$ & $\mathrm{C}=11.35$ & $\mathrm{~T}=6.68$ & $C=7.89$ \\
\hline
\end{tabular}

Table (7): Free, conjugated and total phenol contents of potato Lady-Roseta cv.infested with highly virulent isolate of $R$. solani

\begin{tabular}{|c|c|c|c|}
\hline \multirow{2}{*}{ Treatment } & \multicolumn{4}{|c|}{ Amount of free, conjugated (C) and total phenols mg/g dry weight } \\
\cline { 2 - 4 } & Free & Conjugated & Total \\
\hline $\begin{array}{c}\text { Trichoderma } \\
\text { harzianum }\end{array}$ & 2.77 & 2.07 & 4.77 \\
\hline Bacillus subtilis & 2.24 & 2.00 & 4.31 \\
\hline Spiruliua platensis & 1.70 & 1.18 & 2.88 \\
\hline Pigeons manure & 1.37 & 0.90 & 2.27 \\
\hline Rizolex 50\% WP & 1.03 & 0.78 & 1.81 \\
\hline Control & 0.70 & 0.61 & 1.31 \\
\hline
\end{tabular}


M.A. Khalil, et al.,

Table (8): Determination of oxidative enzyme contents of potato Lady-Roseta cv. sown in the infested with the highly virulent isolate of $R$. solani

\begin{tabular}{|c|c|c|}
\hline \multirow{2}{*}{ Treatment } & \multicolumn{2}{|c|}{ Oxidative enzymes } \\
\cline { 2 - 3 } & Peroxidase & Polyphenoxidase \\
\hline $\begin{array}{c}\text { Trichoderma } \\
\text { harzianum }\end{array}$ & 1.74 & 1.33 \\
\hline Bacillus subtilis & 1.68 & 0.32 \\
\hline Spiruliua platensis & 1.65 & 0.29 \\
\hline Pigeons manure & 1.64 & 0.26 \\
\hline Rizolex 50\% WP & 1.38 & 0.24 \\
\hline Control & 1.22 & 0.22 \\
\hline
\end{tabular}

\section{Discussion}

During growing season 2015 eight fungal isolates representing different localities in different governorates were isolated from naturally infected plants, in Egypt were identification using characteristics of the mycelia as described by Gilman (1957), Barnett and Hunter (1972) and using the key adopted by Sneh et al (1991). Eight isolates of $R$. solani were tested for their ability to anastomosis with a tester isolate (AG-3), which were isolated from El-Kassasen (Ismailia Gov.), Kafer El-zayat (Gharbia Gov.), El-Katatba (Minofya Gov.), HoushEssa (Behera Gov.), El-Badrashen (Giza Gov.), Behdal (Minia Gov.), Dairoot (Assiut Gov.) and Shandaweel (Sohag Gov.).

Ismailia (El-Kassasen, No 1), Gharbia (Kafer El-zayat, No 2), Minofya (ElKhatatba, No 3) Giza (El-Badrashen, No 4) and Minia (Behdal, No 5) fused perfectly with the tester isolate (AG-3). While the isolates of $R$. solani which were isolated from, Behera (Housh-Essa, No 6), Assiut (Dairoot, No 7) and Sohag (Shandaweel, No 8) showed no anastomosis reaction was observed between them and the tester isolates (AG3).This in agreement with the previous reports which showed that AG-3 isolates are specialized to potato and AG-3 is the most severe pathogen of potato among the different AGs (Banville, 1989; Lehtonen et al., 2009 and Woodhall et al.2012). Moreover ElBakali and Martin (2006) noted that black scurf of potato is a serious disease commonly observed in most potatoproducing areas of the world and it is caused by $R$. solani AG-3. Data showed also that, the isolates different in culture colour, number and size of sclerotia. These results are in agreement with those obtained by Wick et al., (2001) and Tuncer and Eken, (2013). Pathogenicity test of $\mathbf{5}$ isolates of $\boldsymbol{R}$. solani were carried out using Lady-Roseta cv. under greenhouse conditions. The results indicated that, all tested isolates were able to infect potato plants causing Rhizoctonia disease symptoms (ungerminated eyes, dead sprouts, stem cankers and black scurf) with different degrees of disease severity. Pathogenic properties of isolates varied from weak to strong but the isolate obtained from Giza (El-Badrashen) (No 4) was the highest aggressive one.

Under greenhouse conditions, application of bio-agent isolates $T$. harzianum or B.subtilis marine algae extract, S. platensis or $C$. valgaris were tested against the highly virulent isolate of $R$. solani (No. 4). Soil treatment with 
the bioagent isolates was effective in decreasing Rhizoctonia symptoms on potato plants. Data indicated that $T$. harzianum showed the highest effect on the disease incidence and gave the best control of the disease at $2.0 \%$ concentration followed by $B$. subtilis and S. platensis. Moreover C. valgaris, gave the lowest effect in controlling stem canker and black scurf disease. These results are in agreement with those obtained by Tsror et al., (2001); Abada and Abdel-Aziz, (2002); Yao et al., (2003); Larkin, (2007); El-Kot, (2008); Wilson et al., (2008 a,b) and Zhang and Wang (2012). In their studies they mentioned that, supplementation $T$. harzianum, or $B$. subtilis, to the soil led to increase their efficacy against root rot incidence of cucumber, cantaloupe, tomato, pepper and potato. The ability of Trichoderma to reduce diseases caused by soil-borne pathogens related to their antagonistic properties, which involve parasitism and lysis of pathogenic fungi and competition for limiting factors in the rhizosphere mainly iron and carbon (Sivan and Chet, 1986). On the other hand, Previous results are in agreement with the findings of Pratt et al., (1944) found that different species algae Chlorella, inhibitory significant against antimicrobial activity of fungi or bacteria and similar finding were detected by Debro and Ward (1979) recorded that the ethanol extracts from 24 species of green algae were found to have extracts of fourteen algae exhibited significant inhibitory activity against either staphylococcus aureus or B. subtilis. Similar results were obtained by Hornesy and Hide (1985); El-Baz et al. (1985) and El-Naggar (1987) found that extracts from marine algae and fresh water algae inhibitory antibacterial and antifungal activity. Likewise, noted that different extracts of Dictycota dichotoma var. implexa antimicrobial activity on bacteria and fungi by Hashem (Fatima) 1989. Also, similar results are in agreement with those reported by Roberts et al., (2005) and Erol and Turali, (2009) found that, culture filtrates or cell extracts from cyanobacteria and algae applied to seeds protect them from damping-off fungi such as Fusarium sp., Pythium sp and Rhizoctonia solani. The strains produced a nonvolatile metabolite that inhibited growth of pathogenic fungi. All tested treatment were effective in reducing the percentage of ungermination eyes, dead sprouts and increased survival plants as well as improved plant growth characters and reducing stem canker or black scurf compared to the control.

Soil amended with animal manure (Chicken and Pigeons) extracts, reduced disease severity either ungermination eyes, dead sprouts and stem canker or black scurf. Generally, addition of the manures to the soil has a beneficial effect on the disease. Results obtained in this investigation are in agreement with those found by many investigators Tsror et al., (2001); Shaikh and Ghaffar (2004); Hamid et al., (2006); Larkin, (2008); Saadi et al., (2010) and Ahmed et al., (2012). Data indicated that, manure, Chicken and Pigeons reduced the disease severity with all parameters (eyes germination inhibition, killing sprouts, stem canker and black scurf). Concentration $2 \%$ of manure extracts was the more effective on the disease reduction than concentrations $0.5, \quad 1.0 \%$. Pigeons manure was the best in controlling the disease with all parameters compared to Chicken manure. This may be due to the beneficial effect of manure on microflora including compost-derived microorganism compete for nutrients with plant pathogens in the rhizosphere (De-Brito et al., 1995). Or they have an effect on reduce sclerotia formation on the surface of tubers and hence disease incidence. Mechanism involves parasitism and production of soil inhabiting pathogens by compost 
M.A. Khalil, et al.,

inhabiting beneficial microorganisms (Hoitink and Boehm, 1999). Also, they mentioned that application of fresh chicken manures was highly effective in reducing the incidence of Verticillium wilt, potato scab and the population of plant parasitic nematodes. Chicken manures application increased soil $\mathrm{pH}$ and led to detectable quantities of ammonia and nitrite accumulation in the soil. Ammonia production from poultry manure amended soil has been reported by Tsao and Oster (1981). The obtained results from, cattle manure compost amendment (CMC-H) applied in furrow could reduce black scurf incidence in organically grown potatoes (Tsror et al., 2001). Similar results were reported by Nelson and Boehm (2002) showed that extracts prepared from 50:50 mixture of chicken manure and cow manure compost were more efficient in reducing root rot caused by Pythium sp. than others prepared from leaves.These results are partially in agreement with those reported by (Pane et al., 2011) indicated that peat amended with compost reduced disease damping-off caused by $P$. ultimum, $R$. solani and $S$. minor in $60 \%$ of the mixtures and compost derived from animal manure showed the largest and most consistent disease suppression.

Likewise, application of Rizolex $\mathbf{5 0 \%}$ WP (Tolchlophos-methyl) and/or Monceren 25\%WP (Pencycuron) to the soil before and after sowing influenced significantly reduction in dead sprouts, gunermination eyes, stem cankers, black scurf and increased survival plants as well as improved plant growth characters compared to the control. Generally, Rizolex 50\% WP (Tolchlophos-methyl) caused the highest effect on the disease control when applied before inoculation and significantly decreased disease severity. Many results of researchers mentioned the efficacy of fungicides in controlling of black scurf disease (Rauf et al., 2007-c, Idrees et al., (2009)). Rauf et al. 2007-b evaluated various fungicides Viz., Pencycuron, Mancozeb, and Benlate against black scurf in field trials and found that Pencycuron was the best fungicide against the disease. The sclerotial viability of Rhizoctonia solani was greatly reduced by the treatment of potato seeds using Pencycuron, Daconil and a dicarboximide fungicides, Rovral (Campion et al., 2003).

On the other hand, treatment, by $T$. harzianum, gave highphenolic compounds, in inoculated potato plants compared with the check (non-inoculated plants). Phenol contents play an important role in plant resistance. Similar results were obtained by added and described by Deborah et al. (2000) who mentioned that the oxidation products of phenolic compounds appear to be involved in the defense of plants invading pathogens, including fungi, bacteria and viruses. As well, fractionation of phenolic compounds showed similar trend where free, conjugated and total phenols contents were less to some extent in non-infected healthy potato plants of Lady-Roseta cv. than those observed in other treatments. In addition, results revealed also that treatment, by $T$. harzianum, gave lowphenolic compounds in non-infected healthy potato plants of Lady-Roseta cv. compared with the infection with the inoculated potato plants by virulent isolate of $\boldsymbol{R}$. solani. It could be concluded that the high levels of phenols became toxic and inhibited the growth of the invading fungi. On the other hand, treatment by $T$. harzianum, gave higher activities of oxidative enzymes, i.e. Peroxidase (PO) and Polyphenoloxidase (PPO) were considered in stem potato samples of susceptible cv.Lady-Roseta after inoculation with $R$. solani. Obtained results showed that inoculated potato plants had a higher Peroxidase and Polyphenoloxidase activity than the non- 
inoculated plants. Similar results are in agreement with those reported by Jindal (2000) who found that a clear correlation between the oxidative enzymes, phenolic compounds content and the resistance of plant diseases. The participation of an endogenous supply of phenolic compounds in plant disease resistance in depended upon the activity of oxidative enzymes (polyphenol oxidase and peroxidase). Phenols are oxidized to Quinone or semi-Quinone's which play a great role as antimicrobial. Such results are in agreement with the findings of Cigdem and Merih (2008) indicate that, Trichoderma harzianum able to produce relatively high concentrations of cell wall degrading enzymes as beta 1, 3 glucanase and chitinase enzymes which affect the pathogen

\section{REFERENCES}

Abada, K. A. and M. A. Abdel-Aziz (2002). Biological and chemical control of stem canker and black scurf on potato in Egypt Bulletin of Faculty of Agriculture, Cairo University, 53 (1): 115-128.

Ahmed, S., N. Zaman and S. N. Khan (2012). Evaluation of maturing practices on root rot disease and agronomic characters of Arachis hypogeae African Journal of Biotechnology, 11 (5): 1119-1122.

Allam, A. I. and Hollis (1972). Sulfide inhibition of oxidase in nice root. Phytopathology, 62: 634-639.

Almeida, F.B.R., F.M. Cerqueira, R.N. Silva, C.J. Ulhoa and A.L. Lima (2007). Mycoparasitism studies of Trichoderma harzianum strains against Rhizoctonia solani: evaluation of coiling and hydrolytic enzyme production. Biotechnology. Lett. 29 (8), 1189-1193.

Anderson, N. A. (1982). The genetics and pathology Rhizoctonia solani. Annual Rev. Pathol. 20: 329-342.
Banville, G. J. (1989). Yield losses and damage to potato plants caused by Rhizoctonia solani Kuhn. American Potato Journal, 66 (12): 821-834.

Barnett, H.L. and B.B. Hunter (1972). Illustrated Genera of Imperfect Fungi. $3^{\text {rd }}$ ed. Burgess Publishing Company, Minneopolis. Mineosta, 1241pp.

Benitez, T., A. M. Rincon, M. C. Limon and A. C. Codon (2004). Biological mechanisms of Trichoderma strains. Int. Microbiol, 7: 249-260.

Burbage, D. A., M. Sasser and R. D. Lumsden (1982). A medium selective for Pseudomonas cepacia (Abstrac.). Phytopathology, 72: 706.

Campion, C., C. Chatot, B. Perraton and D. Andrivon (2003). Anastomosis groups, pathogenicity and sensitivity of fungicides of Rhizoctonia solani isolates collected on potato crops in France. European Journal of Plant Pathology, 109 (9): 983-992.

Carling, D. E. and R. H. Leiner (1986). Isolation and characterization of Rhizoctonia solani and binucleate $R$. solani-like fungi from aerial stems and subterranean oranges of potato plants. Phytopathology, 76: 725-729.

Carling, D. E. and R. H. Leiner (1990 a). Virulence of isolates of Rhizoctonia solani AG-3 collected from potato plant organs and soil. Plant Disease, 74 (11): 901-903.

Carling, D. E. and R. H. Leiner (1990 b). Effect of temperature on virulence of Rhizoctonia solani and other Rhizoctonia on potato. Phytopathology, 80:930-934.

Cigdem, K. and Merih (2008). Effect of carbon source on production of lytic enzymes by Trichoderma harzianum Journal of Applied Biological Sciences, 2 (2): 23-26.

Cunnington, S. (2008). Development in potato storage in Great Britain. Potato Research, 51 (3-4): 403-410. 
Deborah, S. D., A. Palaniswami, P. Vidhyasekaran and $R$. Velazhahan (2000). Time cource study of the induction of defence enzymes, phenolics and lignin in rice response to infection by pathogen and noonpathogen. Zeitschrift fur Pflanzenkrankheiten und Pflanzenschutz, 108 (2):204-216.

De-Brito, A., S. Gagne and H. Antoun (1995). Effect of compost on rhizosphere microflora of the tomato and on the incidence of plant growthpromoting rhizobacteria. Applied and Environmental Microbiology, 61: 194199.

Debro, L. H. and H. B. Ward (1979). Antibacterial activity of fresh water green algae. J. Med. PI. Rec., 36: 357378.

Domsch, K. H., W. Games and A. Trauteeidi (1980). Compendium of soil fungi. Academic Press A subsidiary of Harcout Brace Jovanovich, Publisher, London, 1: 859pp.

Elad, Y. (2000). Biological control of foliar pathogens by means of Trichoderma harzianum and potential modes of action. Crop Protection, 19: 709-714.

El-Bakali, A. M. and M. P. Martin (2006). Black scurf of potato. Mycologist, 20: 130-132.

El-Baz, F. K., S. M. S. Bader El-Din and M. S. M. Saber (1985). The presence of antimicrobial substances in certain green algae. Egypt J. Microbiol., 20: 57-60.

El-Kot, G.A.N. (2008). Biological control of black scurf and dry rot of potato. Egypt. J. Phytopathology, 36 (1-2): 4556.

El- Naggar, M. E. F. (1987). Antimicrobial activity of some marine algae of Egypt. Mansoura Science Bulletin., 14 (2): 189-201.

El-Masry, M. H., A.l. Khalil, M. S. Hassouna and H. A. H. Ibrahim (2002). In situ and in vitro suppressive effect of agricultural composts and their water extracts on some phytopathogenic fungi. World Journal Microbial, Biotechnology, 18: 551-558.

Erol, F. Y. and B. Turali (2009). Determination of root and crown rot diseases in tomato growing area of samsun province. Acta Horticulturae, vol. 808, pp 65-69, 2009.

Gilman, J.C. (1957). Manual of Soil Fungi. lowa State Univ. Press. Ames, Iowa. USA, 1- 418 pp.

Gomez, K. A. and A. A. Gomez (1984). Statistical Procedures for agricultural research $2^{\text {nd }}$ ed. John Wily. New York. 680pp.

Grosch, R., F. Faltin, J. Lottmann, A. Kofoet and G. Berg (2005). Effectiveness of 3 antagonistic bacterial isolates to control Rhizoctonia solani Kuhn on lettuce and potato.

Hashem, Fatma, A. (1989). Phytochemical and biological study of Dictycota dichotoma. M. Sc. Thesis, pharmacology Dept. Faculty of Pharmacy, Cairo Univ.

Hamid, Eklas, E., Y. E. Himeidan and S. M. El- Hassan (2006). Cultural practices for the management of Rhizoctonia disease in potato J. King Saud Univ., 18(2): 141-148.

Hausvater, E. and J. Trukova (1993). The effectiveness of chemical and biological protection of potato against Rhizoctonia solani Kuhn. Rostlinna Vyroba, 39(11): 1019-1026.

Hoitink, H. A. J. and M. J. Boehm (1999). Biocontrol within the context of soil microbial communities: A substratedependent phenomenon. Ann. Rev. Phytopathology, 37: 427-446.

Hornsey, I. S. and D. Hide (1985). The production of antimicrobial compounds by British marine algae. IV. Variation of antimicrobial activity with algal generation Br. Phycol. J., 20 21-25.

Howell, C.R. (2003). Mechanisms employed by Trichoderma species in 
the biological control of plant diseases. The history and evolution of current concepts. Plant Disease, 87:410.

Idrees, M., S. Ali, M. Ayub, M. Z. Niaz and Q. Ali (2009). Impact of seed dressing on soil borne potato tubers disease. Pak. J. Phytopathology. 21: 89-91.

Jager, M.J., G. A. Hide, P. H. J. F. Van Den Boogert, A. J. Termorshuizen and P. Van Baarlen (1996). Pathology and control of soil borne fungal pathogens of potato. Potato Research, 39: 437469.

Jindal, P.G. (2000). Biochemical disease resistance studies against anthracnose of grape. J. Horticulture Science, 29 (1): 11-14.

Larkin, R. P. (2007). Effects of biological amendments on black scurf and common scab of potato. Plant Disease Management Reports. Report 2: vol, 52.

Larkin, R. P. (2008). Relative effects of biological amendments and crop rotations on soil microbial communities and soil-borne diseases of potato. Soil biology and biochemistry, 40(6): 1341-1351.

Lehtonen, M. J., P. Ahvenniemi, P. S. Wilson, M. German-Kinnari and J. P. T. Valkonen (2009). Formation of canker lesions stems and black scurf on tubers in experimentally inoculated potato plants by isolates of AG2-1,AG3 and AG-5 of Rhizoctonia solani a pilot study and literature review. Agricultural and Food Science, 18: 223-233.

Lorito, M., E. Harman, C. K. Hayes, R. M. Broadway, A. Tronsmo, S. L. Woo and A. Di Pietro (1993). Chitinolytic enzymes produced by Trichoderma harzianum antifungal activity of purified endochhitinase and chitobiosidase. Phytopathology, 83 (3): 302-307.

Malik, O., S. Chohan and S.A.H. Naqvi (2014). Occurrence of black scurf disease of potato in Multan (Punjab) along with its in vitro Chemical and Biotic Elicitor Mediated Management. Journal of Agricultural Science, 6 (9): 134- 143.

Maxwell, D. P. and D.F. Bateman (1967). Change in the activities of some oxidases in extracts of Rhizoctonia infected bean hypocotyls in relation to lesion maturation. Phytopathology, 57: 132-136.

Mohamed, A. Abd-Alla, Nehal S. ElMougy, M. M. Abd-El-Kader, F. Abd-ElKareem, Nadia G. El-Gamal and Ried S. R. El-Mohamedy, 2013. Aldehydes compounds for controlling black scurf disease of potato (Solanum tubrosum

L.) under field conditions. International Journal of Agriculture and Forestry 3(2): 34-39.

Mohamed A. Abdel-Sattar; Hanan ElMarzouky and Usama E. Ibrahim 2017. Pathogenicity test and anastomosis group of Rhizoctonia solani the causal organism of stem canker and black scurf disease of potato in Egypt. Journal of Applied Plant Protection; Suez Canal University 6 (1): 1-8.

Moeau, J., D. Pesando and B. Caram (1984). Antifungal and antibacterial screening of Dictyotales from the French Mediterranean coast. Hydrobiologia, 117: 521-524.

Naz, F. (2006). Integrated management of black scurf of potato. Ph. D. Thesis, Plant Pathol. Dept. Fac. Crop and Food Science, Arid Agriculture Univ., Rawalpindi, Pakistan.

Naz, F., C.A. Rauf, N.A. Abbasi, I.U. Haque and I. Ahmad (2008). Influence of inoculum levels of Rhizoctonia solani and susceptibility on new potato germplasm. Pak. J. Bot., 40 (5): 2199-2209.

Nelson, E. B. and M. J. Boehm (2002). Microbial mechanics of composted induced disease suppression. Part II. Biocycle, 43(7): 45-47. 
Pane, C., R. Spaccini, A. Piccolo, F. Scala and G. Bonanomi (2011). Compost amendments enhance peat suppressiveness to Pythium ultimum, Rhizoctonia solani and Sclerotinia minor. Biological control, 56(2):115124.

Papavizas, G. C. and C. B. Davery (1959). Isolation of Rhizoctonia solani Kuhn from naturally infested and artificially inoculated soils. Plants Dis. Report, 43: 401-410.

Parameter, J. J., R. T. Sherwood and W.D. Platt (1969). Anastomosis grouping among isolates of Thanatephorus cucumeris. Phytopathology, 59: 12701278.

Pesando, D. and B. Caram (1984). Screening of marine algae from the French Mediterranean coast. For antibacterial and antifungal activity. Bot. Mor., 27: 3281-3286.

Pratt, R., T. C. Daniels, J. J. Eiler, J. B. Gunnison, W. D. Kulmer, J. F. Oneto, L. A. Strait, H. A. Spoenr, G. J. Hardin, H. W. Milner, J. H. C. Smith and H. H. Strain (1944). Chlorellin, an antibacterial substance from Chlorella. Science, 99: 351-352.

Raj, H. and I. J. Kapoor (1997). Possible management of Fusarium wilt of tomato by soil amendments with composts. Indian Phytopath, 50(3): 387-395.

Rauf, C.A., I. Ahmad and M. Ashraf (2007a). Anastomosis groups of Rhizoctonia solani kühn isolates from potato in Pakistan. Pak. J. Bot., 39(4): 1335-1340.

Rauf, C.A., M. Ashraf and I. Ahmad (2007b). Occurrence and distribution of black scurf of potato in Pakistan. Pak. J. Bot., 39 (4): 1341-1352.

Rauf, C. A., M. Ashraf and I. Ahmad (2007-c). Management of black scurf disease of potato. Pak. J. Bot., 39(4): 1353-1357.

Roberts, D. P., S. M. Ohrke, S. L. F. Meyer, J. S. Buyer and J. H. Bowers
(2005). Bio-control agents applied individually and in combination for suppression of soil borne diseases of cucumber, Crop Protection, vol. 24, pp. 141-155

Saadi, L., Y. Laor, S. Medina, A. Krassnovsky and M. Raviv (2010). Compost suppressiveness against Fusarium oxysporum was not reduced after one-year storage under various moisture and temperature conditions. Soil Biology and Biochemistry, 42(4): 626-634.

Scholte, K. and M. Lootsma (1998). Effect of farmyard manure and green manure crops on populations of mycophagous soil fauna and Rhizoctonia stem canker of potato. Pedobiologia 42:223-231.

Shaikh, A. H. and A. Ghaffar (2004). Effect of poultry manure and sawdust on survival of sclerotia Macrophomine phaseolina in soil Pak. J. Bot., 36(2): 425-428.

Sneh, B., I. Burpee and A. Ogoshi (1991). Identification of Rhizoctonia species. St. Paul, MN.USA. APS Press, pp. 133.

Snell, F.D. and C.L. Snell (1953). Colorimetric Methods of Analysis Including some Tubidimetric and Nephalometric Methods. Vol. 111, D.VanNostrand Company Inc., Pirnceton, New Jersey, Toronte-New York, London. 606 pp.

Sivan, A. and I. Chet (1986). Biological control of Fusarium spp. in cotton, wheat and muskmelon by Trichoderma. Journal of Phytppathologische Zeitschrift, 116: 39-47.

Tsao, P. H. and J. J. Oster (1981). Relation of ammonia and nitrous acid to suppression of Phytophthora in soils amended with nitrogenous organic substances, Phytopathology, 71: 53-59.

Tsror, L., R. Barak and B. Sneh (2001). Biological control of black scurf on 
potato under organic management. Crop Prot., 20:145-150.

Tuitert, G., M. Szczech and G.J. Bollen (1998). Suppression of Rhizoctonia solani in potting mixtures amended with compost made from organic household waste. Phytopathology 88:764-773.

Tuncer, S. and C. Eken (2013). Anastomosis grouping of of Rhizoctonia solani and binucleate Rhizoctonia spp. Isolated from pepper in Erzincan, Turkey. Plant Protection Science, 49 (3): 127-131.

Virgen-Calleros, G., V. Olalde-Portugal and D.E. Carling (2000). Anastomosis groups of Rhizoctonia solani on potato in Central Mexico and potential for biological and chemical control. American Journal of Potato Research, 27(4): 219-224.

Wharton, P., W. Kirk, D. Berry and S. Snapp (2006). Rhizoctonia stem canker and black scurf of potato. Department of Plant Pathology, Michigan State University http://potatodiseases.org/earlyblight.h tml.

Wick, T., R. Hali and R. Thurn (2001). Rhizoctonia or black scurf on potato. South Austrailan Research and Development Institute, Plant Research Centre, Hartley Grove, Urbane South Australia, 50-54.

Wilson, P. S., E. O. Ketola, P. M. Abvenniemi, M.J. Lehtonen and J.P.T. Valkonen (2008-a). Dynamics of soilborne Rhizoctonia solani in the presence of Trichoderm harzianum effects on stem canker, black scurf and progeny tuber of potato. Plant Pathology, 57 (1): 152-161.

Wilson, P S., E O. Ketola, P M. Abvenniemi, M J. Lehtonen and $\mathbf{J} P \mathrm{~T}$. Valkonen (2008-b). Biological and chemical control and their combined use to control different stages of the Rhizoctonia disease complex on potato through the growing season. Annals of Applied Biology, 153 (3): 307-320.

Windels, C. E. and S. J. Nabben (1989). Characterization and pathogenicity of anastomosis group of Rhizoctonia solani isolated from Beta vulgaris. Phytopathology, 79: 83-88.

Woodhall, J., A. Lees, S. Edwards and P. Jenkinson (2008). Infection of potato by Rhizoctonia solani: effect of anastomosis group. Plant Pathology, 57(5): 897-905.

Woodhall, J.W., A.K. Lees, S.G. Edwards and $P$. Jenkinson (2012). First report of a new binucleate Rhizoctonia on potato tuber in the UK. New Disease Reports, 23: 31.

Yanar, Y., G. Yilmaz, I. Cesmeli and S. Coskun (2005). Characterization of Rhizoctonia solani isolates from potatoes in Turkey and screening potato cultivars for resistance to AG-3 isolates. Phytoparasitica, 33 (4): 370376.

Yao, M.K., H. Désilets, M. Charles, R. Boulanger and R.J. Tweddell (2003). Effect of mycorrhization on the accumulation of rishitin and solavetivone in potato plantlets challenged with Rhizoctonia solani. Mycorrhiza, 13(6):333-336.

Youssef-Sahar, A. (2007). Evaluation of composted chicken manure in biocontrolling Fusarium wilt on tomato. Egypt. J. Phytopathol., 35 (1): 61-72.

Zhang, Ru and Di. Wang (2012). Trichoderma spp. from rhizosphere soil and their antagonism against Fusarium sambucinum. African Journal of Biotechnology, 11(18): 4180-4186. Potato Canada. J. Microbial., 51: 345-353. 
فعالية أستخدام بعض كائنات المكافحة الحيوية والمخلفات الحيوانية والمبيدات الفطرية فى مقاومة مرض القشرة السوداء وتقرح الساق فى البطاطس

\author{
محمد علي خليل ، سهام سمير رجب، أمل محمد اسماعيل
}

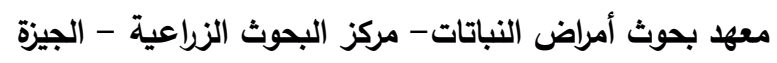

الملخص العربى

فى السنوات القليلة الماضية أتضح أن مرض تقرح الساق والقشرة السوداء والمتسبب عن الفطر ريزوكتونيا سولانى هوأحد أهم الأمراض التى تهاجم محصول البطاطس تحت ظروف الطقس لجمهورية مصر العربية. حيث تم عزل 8 عزئل 8 عزلات

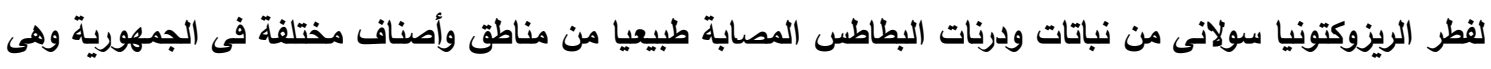

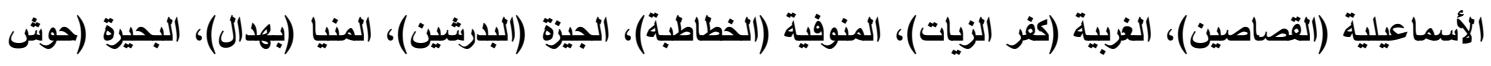

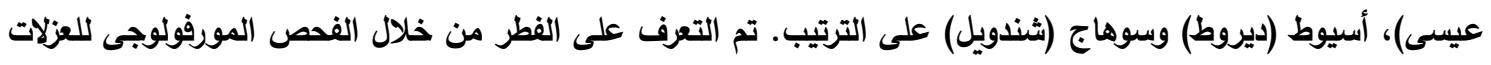

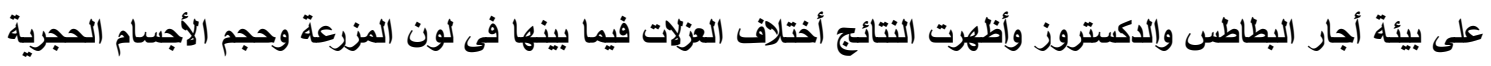

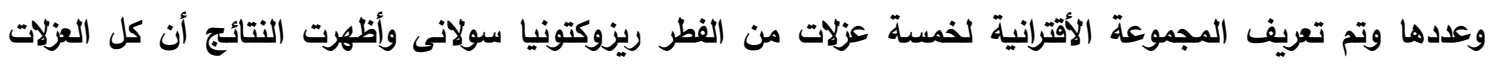

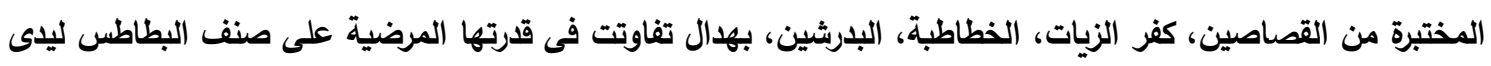

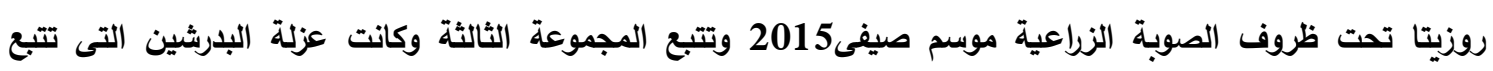
محافظة الجيزة هى أقوى العزلات قدرة مرضية. تحت ظروف الصوبة الزراعية أدى أضافة كائنات التضاد الحيوى، ترايكودرما هاريزيانم وبكتريا باسيلس ساتلس أو أو إونائ

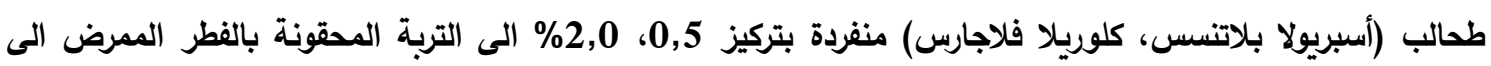

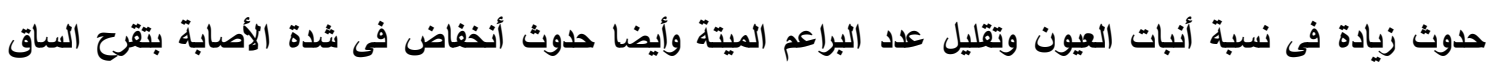

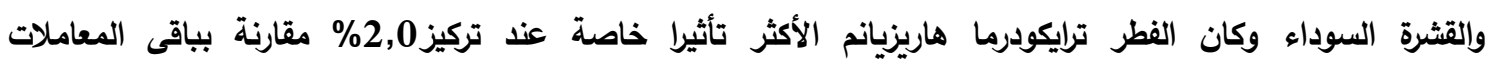

والكونترول.

كنلك عذ أضافة مخلفات (الدواجن والحمام) الى التربة قبل الززاعة بأسبوعين بتركيز 0.5، 1,0، 2,0\%

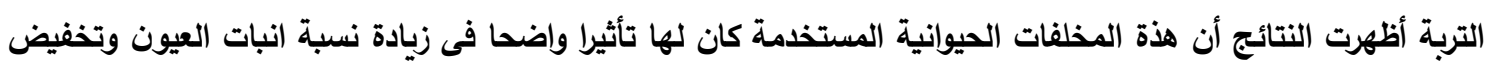

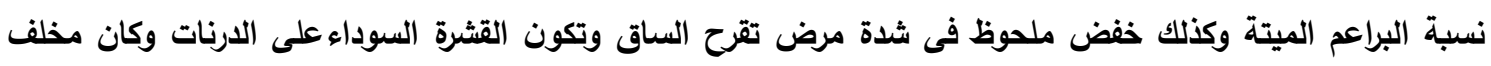

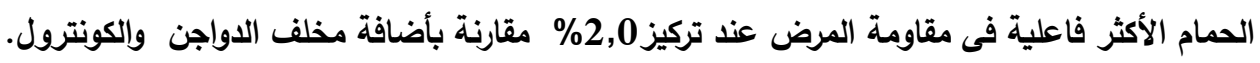
أدت معاملة الدرنات بالمبيدات الكيماوية ريزولكس ومونسرين قبل أو بعد عدوى التربة المعقمة بالفطر ريزوكتونيا

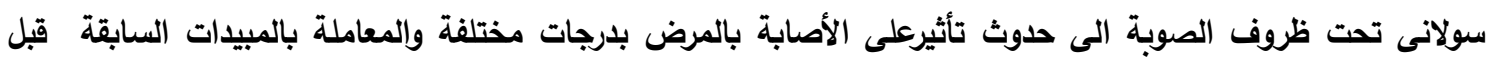

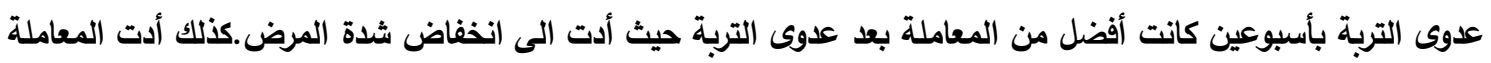

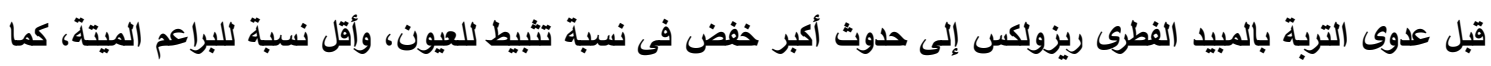
نقصت شدة الإصابة بتقرح الساق والقشرة السوداء مقارنة بمبيد بالمعاملة بالمبيد الفطرى مونسرين والكونترول. 
أيضا أدت أضاقة كلا من فطر ترايكودرما هاريزيانم وبكتريا باسيلس ساتلس أو طحلب أسبريولا بلاتنسس بتركيز2,0\%

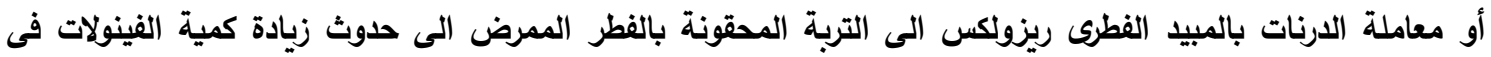
نباتات البطاطس المصابة (صنف ليدى روزيتا) مقارنة بالسليمة. وعند قياس النثاط الأنزيمى لكل من أنزيم البيروكسيديز والبولى فينول أكسيديز تبين أن أفراز الفطر لهذة الأنزيمات كان بدرجات مختلفة على نباتات البطاطس عند معاملتها

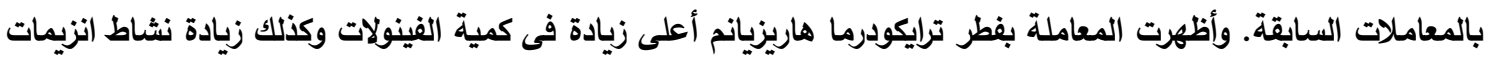
الأكسدة (البيروكسيديز والبولى فينول أكسيديز) مقارنة بباقى المعاملات والكونترول.

$$
\begin{aligned}
& \text { أ.دماء عماد الدادة المحكمين يوسف مركز البحوث الزراعية - الجيزة }
\end{aligned}
$$

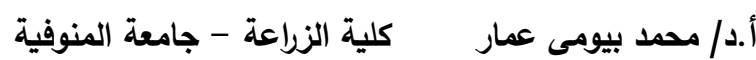


M.A. Khalil, et al., 